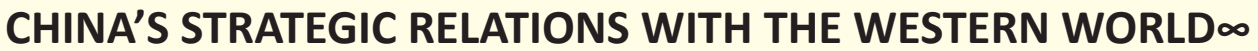

\author{
BERNARD D. COLE ${ }^{*}$
}

\begin{abstract}
This paper's topic, "China's Strategic Relations With the Western World," discusses some economic and military aspects of the People's Republic of China's (defined as the PRC or "China") relations with the West-a very large and varied geographic region, defined as North America, Western Europe, and Latin America, the last further defined to include South America, Central America, Mexico, and the Caribbean. Even within that definition, however, discussion is sharply focused due the brevity of this paper.
\end{abstract}

\section{LAS RELACIONES ESTRATÉGICAS DE CHINA CON EL MUNDO OCCIDENTAL}

\section{Resumen}

El tema de este artículo, "Las relaciones estratégicas de China con el mundo occidental", analiza algunos aspectos económicos y militares de las relaciones de la República Popular China (definida como la República Popular China o "China") con Occidente, una región geográfica muy grande y variada, definida como América del Norte, Europa Occidental y América Latina, la última más definida para incluir América del Sur, América Central, México y el Caribe. Sin embargo, incluso dentro de esa definición, el debate se centra claramente debido a la brevedad de este documento

\section{AS RELAÇÕES ESTRATÉGICAS DA CHINA COM O MUNDO OCIDENTAL}

\section{RESUMO}

O tema deste artigo, "As Relações Estratégicas da China com o Mundo Ocidental", discute alguns aspectos econômicos e militares das relações da República Popular da China (definida como A RPC ou "China") com o Ocidente - uma região geográfica muito grande e variada, definida como América do Norte, Europa Ocidental e América Latina, a última definida para incluir América do Sul, América Central, México e Caribe. Mesmo dentro dessa definição, no entanto, a discussão está fortemente focada devido à brevidade deste artigo.

œ Fecha de recepción: 280320 - Fecha de aceptación: 151220.

- A.B. in History, University of North Carolina; M.P.A. in National Security Affairs, University of Washington; y Ph.D. in History, Auburn University. Publicaciones: "China and the South China Sea (2016);" China's Quest for Great Power: Ships, Oil, and Foreign Policy in China ( 2016)"; "Asian Maritime Strategies" (2014), "Sea Lanes and Pipelines: Energy Security in Asia (2013)", "The Great Wall at Sea: China's Navy in the 21st Century (2010)"; "Taiwan's Security: History and Prospects (2006)". Estados Unidos. comdesron35@comcast.net ORCID: https//orcid.org/0000$\underline{0001-5010-8800}$ 


\section{Introduction}

This paper's topic, "China's Strategic Relations With the Western World," discusses some economic and military aspects of the People's Republic of China's (defined as the PRC or "China") relations with the West-a very large and varied geographic region, defined as North America, Western Europe, and Latin America, the last further defined to include South America, Central America, Mexico, and the Caribbean. Even within that definition, however, discussion is sharply focused due the brevity of this paper.

The discussion describes Chinese priorities, programs, and strategic paradigms that are also applicable to other global areas, such as East, South, and Central Asia; Africa; the Middle East; and Russia. The paper's goal is to understand the rationale behind Beijing's policies and strategy regarding Western nations, while offering possible guidelines for anticipating future Chinese economic and military policies when operating in the international arena. The methodologies involved in pursuing this objective include reviewing relevant history, analyzing current geopolitical circumstances, and applying a rational actor model to those factors.

As noted in this paper's conclusion, Beijing has established and long practiced policies to support a national strategy designed to first, maintain the Chinese Communist Party (CCP) in power, and second, to support that goal by maintaining a growing economy. These policies are coincident with a very strong sense of nationalism in China, one that still seriously resents the so-called "100 years of humiliation," that lasted approximately from 1842-1949, when Western nations and Japan systematically and thoroughly violated China's sovereignty. This in turn influences an equally strong sense of sovereignty, currently focused on border issues with India, the status of Taiwan, insular clams in the East and South China Seas, and lesser disputes with North and South Korea.

These concerns in part emerge from a sense of history that in turn contributes mightily to current Chinese nationalism. Indeed, China led the world in many categories during the past two millennia. These included education, the arts, science, administration, and military developments both ashore and at sea. That period deteriorated during the nineteenth century and ended with the 1911 downfall of the Qing Dynasty, the last imperial government to rule China.

While not a "hermit kingdom," at title applied to nineteenth century Korea, or even the seclusion of the Japanese islands during the eighteenth and earlier centuries, imperial China's relations with the West were very limited, restricted more by geography as by governmental policies.

A more significant general description of China is the translation of its name in Chinese, zhongguo, a name for "China" usually translated as "middle kingdom." This phrase should not be interpreted as meaning that Beijing considers China to be the geographic center of the world. Rather, the phrase more correctly means that China exists in the "middle" between heaven and earth. This is a subtle but important distinction when trying to evaluate Beijing's foreign policy goals, since it contradicts the too-often heard criticism of Beijing's goal as global dominance. 


\section{Domestic Influences: The Middle Kingdom}

Former Speaker of the U.S. House of Representatives Tip O'Neill once declared that "all politics is local." This applies as much in China as it does in the United States, albeit with a very different focus. A national leader, whether elected or self-appointed, democratic or fascist or communist, has a constituency he or she must satisfy at various levels.

Any government ruling China must have the support of the people. This applied to the imperial regimes that were in power from approximately 4000 B.C.E. to 1911, and the warlord regimes and Republican government that spanned the period to 1949, when the People's Republic of China (PRC) was established.

The Chinese Communist Party (CCP) in 1949 became the government of a broken, devastated country, torn by nearly a half-century of civil war and foreign invasion. That condition improved initially, but then waxed and waned-mostly the latter-due to ideological spasms by Mao Zedong. These culminated in the Great Proletarian Cultural Revolution (GPCR) that ravaged the country from 1964 until Mao's death in 1976. Disorder continued until Deng Xiaoping consolidated power in 1978 over other would-be successors to Mao.

Deng set China on the path to recovery from thirty years of Maoist inconsistency and domestic destruction. He emphasized economic modernization as the country's top priority, dependent in part on the following strategy.

- establish and sustain a peaceful environment on China's borders and in the approaches to them,

- avoid forming alliances making enemies, or taking sides in other countries' quarrels,

- keep a low political and military profile,

- cultivate friendship and trade with all nations regardless of their ideology, and

- minimize friction with other countries by reacting to perceived slights and insults with restraint ${ }^{1}$.

China's progress has been remarkable since Deng initiated his modernization programs. It is now the world's largest consumer of energy, second largest and fastest growing economy, and deploys a military second only the United States globally, and by far the strongest in East Asia. Deng's prescription has been changed by current President Xi Jinping with respect to the United States, however, reflecting both China's enormously increased strength since Deng fostered national modernization and by a perceived U.S. decline following the 2008 financial crisis. Xi verbalized this in a 2013 proposal that China and the United States form a "new type of great power relationship," a proposal that received short shrift in Washington ${ }^{2}$. Current Chinese realization of its global strength has

1 Cited in Chas W. Freeman, Jr. "China's National Experiences and the Evolution of PRC Grand Strategy," in David Shambaugh (ed.), China \& the World (N.Y.: Oxford University Press, 2020), 45. Referred to hereafter as "Shambaugh." Trade figures are provided in Appendix A.

2 Discussed in David M. Lampton, "A New Type of Major-Power Relationship: Seeking a Durable 
likewise and more significantly affected its international relations in general.

China's current relations with the other nations of the world are based on a strategy designed to take advantage of extremely strong foundations and national pride.

\section{Global Influence}

The "Five Principles of Peaceful Coexistence" were a product of a 1954 Sino-Indian agreement, but are more commonly remembered from Chinese Premier Zhou Enlai's pronouncement during a meeting of non-aligned nations at Bandung, Indonesia the following year. These remain a commonly held trope for China's theory of international relations. They are

(1) Mutual respect for each other's territorial integrity and sovereignty,

(2) Mutual non-aggression,

(3) Mutual non-interference in each other's internal affairs,

(4) Equality and mutual benefit, and

(5) Peaceful co-existence.

These points emulate the non-interference doctrine described in the 1648 Peace of Westphalia, developed by the European powers at the end of the extremely destructive Thirty Years War that desolated the continent. That conflict had been caused by religious strife; the contestants sought to instill a more rational set of modalities for international relations, including characterizing nations as sovereign states, rather than by their religion or rulers.

Deng Xiaoping adopted the Five Principle of Peaceful Coexistence by emphasizing a cautious approach to improving relations with other nations. In practice, of course, Beijing conducts its relations with other nations very much in a traditional nationalistic fashion. This has been amply demonstrated both in deeds and in words, as will be discussed below. Three statements by Chinese officials are especially relevant.

First, Foreign Minister Yang Jiechi, speaking at the july 2010 meeting of the Association of Southeast Asian Nations (ASEAN) in Hanoi, chastised Singapore Prime Minister Lee Hsien Loong, pointedly stating "China is a big country and other countries are little countries, and that's just a fact" ${ }^{3}$. In other words, China would act internationally whenever and however it liked, whenever and wherever it had the power to do so.

Second, Foreign Minister Wang Yi echoed his predecessor in March 2014. While insisting China would be benevolent toward "smaller countries" in the South China Sea region, Wang expressly told the world that "we will never accept unreasonable demands

Foundation for U.S.-China Ties." Asia Policy 16 (july 2013), 51-68, available through https:// www.jstor.org/stable/24905231?seq=1

3 See Ian Storey, China's Missteps in Southeast Asia: Less Charm, More Offensive," China Brief, v. 10, 25 (17 december 2010), at: https://jamestown.org/program/chinas-missteps-in-southeastasia-less-charm-more-offensive/ 
from little countries"'4.

Finally and most egregiously, a military professor in Beijing stated in 2016 that "China possesses a superior cultural gene needed to become the world's leader"5.

Perhaps more significant than these exasperated and exasperating statements has been Beijing's shift from insisting on bilateral relations as its primary strategy for conducting foreign relations, to an appreciation of and even enthusiastic participation in multilateral organizations. The Chinese role in the United Nations (UN) is a leading example. For instance, Beijing provides more peacekeeping troops to UN missions, over 5,000 , than do the other four permanent members of the Security Council (the United States, Russia, Great Britain, and France) combined.

China has also taken advantage of the Trump administration's withdrawal from the Trans-Pacific Partnership (TPP) to consolidate its position as a regional economic power throughout not only East Asia, but throughout all of Asia and reaching to Europe, Africa, and even Latin America. The similar U.S. withdrawal from the 2016 Paris Climate Accord has opened the way for China to claim world leadership in reducing carbon emissions and by inference, the global leader in environmental concerns. That this role is spurious for a nation renowned for domestic air, water, and ground contamination has neither prevented Beijing's claims nor reduced its increasing role as a global power keen to take the leadership of multi-lateral organizations.

Another example of China's perceiving and adopting multilateralism is its joining the Arctic Council as an associate member in the guise of a self-proclaimed "near-Arctic nation." This nomenclature is unique to Beijing, but has become accepted by the majority of the international community. Finally, China has and continues to play an increasingly active role in the World Health Organization (WHO), World Bank, International Monetary Fund (IMF), the World Trade Organization (WTO), the International Criminal Police Organization (Interpol), and other multilateral organizations. China's participation always maintains a bottom line of "China first," with organization's goals very much a lesser priority ${ }^{6}$.

Beijing's foreign relations still prioritizes its regional neighbors. Its northeast Asia interlocutors, South and North Korea, and Japan are a particular focus, but China's number top foreign concerns are those concerning sovereignty, a list led by Taiwan and including claims in the East China Sea, South China Sea, and its border with India. This regional focus also includes concerns about Australia and the island states of the South and Southwest

4 Quoted in Edward Wong, "China's Hard Line: No Room for Compromise," New York Times (8 march 2014), at: https://www.nytimes.com/2014/03/09/world/asia/china.html

5 Sr. Col. Liu Mingfu, quoted in Maochun Miles Yu, "Understanding China's Strategic Culture Through Its South China Sea Gambit," Hoover Institution (9 may 2016), at:

https://www.hoover.org/research/understanding-chinas-strategic-culture-through-its-southchina-sea-gambit

6 A recent example is discussed in Colin Dwyer, "Former Interpol President Sentenced to Prison for Corruption," NPR (21 january 2020), at: https://www.npr.org/2020/01/21/798121397/ former-interpol-president-sentenced-to-prison-in-china-for-corruption 
Pacific, but none of these are accorded special priority.

Beijing employs economic pressure against nations that have offended it. Examples include cancelling salmon imports from Norway when the Nobel Peace Prize was awarded in 2017 to a prominent Chinese human rights activist, Liu Xiaobo. China's economic punishment lasted six years ${ }^{7}$.

Another case involved the Philippines, following disputes with China over South China Sea claims, when Beijing imposed otherwise unjustified restrictions on Philippine banana imports ${ }^{8}$. A third example is Beijing's ban on the export of rare earth minerals to Japan in 2010, another example of extreme Chinese sensitivities to even minor, perceived insults ${ }^{9}$.

In addition to employing its economic power as a "hammer" in conducting relations with other nations, China also uses the PLA as a diplomatic, as well as a military, instrument of statecraft. Beijing's 1998 Defense White Paper described China's "new security concept," and assigned the mission of "military diplomacy" to the PLA. Hu Jintao further emphasized this role in 2004 as part of his "New Historic Missions" for the PLA, as it has been in subsequent Defense White Papers ${ }^{10}$.

The PLA also manages China's inventory of nuclear weapons. This inventory is dwarfed by those of Russia and the United States, which leads Beijing to engage in negotiating nuclear arms reduction. The small Chinese inventory includes a triad of sorts, with a few fleet ballistic missile submarines and the theoretically nuclear weapons-capable $\mathrm{H}-6$ bomber supplementing the land-based missiles that form the overwhelming category of the nation's nuclear deterrent force.

7 The fact that the Nobel prizes are a Swedish program, and that Oslo simply was the site of the award, attests to Beijing's exaggerated sensitivity and possible ignorance. See Andrew Jacobs and Jonathan Ansfield, "Nobel Peace Prize Given to Jailed Chinese Dissident," New York Times (8 october 2010), at:

https://www.nytimes.com/2010/10/09/world/09nobel.html and Thomas Langhelle, "China Steps Up Retaliation Against Norway for Nobel," Reuters (n.d.), at: https://www.reuters. com/article/us-nobel-peace-china/china-steps-up-retaliation-against-norway-for-nobelidUSTRE6971XY20101012, China Condemns 'Insult' of Award to Jailed Dissident Liu Xiaobo," Independent (9 october 2010), at: https://www.independent.co.uk/news/world/politics/chinacondemns-insult-of-award-for-jailed-dissident-liu-xiaobo-2101810.html

8 "China's Banana Diplomacy With the Philippines," Stratfor (17 may 2016), at: https://worldview. stratfor.com/article/chinas-banana-diplomacy-philippines.

9 BRADSHER, Keith. "Amid Tension, China Blocks Vital Exports to Japan," New York Times (22 september 2010), at: https://www.nytimes.com/2010/09/23/business/global/23rare.html.

10 "White Papers," China's Ministry of National Defense (May 2015), at: http://eng.mod.gov.cn/ Database/WhitePapers/. See James Mulvenon, "Chairman Hu and the PLA's 'New Historic Missions,' China Leadership Monitor, No. 27 (9 january 2009), at: https://media.hoover.org/ sites/default/files/documents/CLM27JM.pdf. Inventories are discussed by Hans Kristensen and Matt Korda, "Status of World Nuclear Forces," Federation of American Scientists (May 2019), at: https://fas.org/issues/nuclear-weapons/status-world-nuclear-forces/ 
China will no doubt continue improving its nuclear force, as indicated by plans to continue modernizing its sea-borne deterrent. There is little evidence that Beijing would alter its "no first use" policy regarding the employment of nuclear weapons, but there is very little doubt that such weapons would be used as a second strike in response to a nuclear attack by the United States or another nuclear-armed nation. The ongoing reorganization of China's military and associated forces also underlines concerns about the effectiveness of its nuclear deterrent. These have been reorganized into the Rocket Force, a new service branch that replaces the old Second Artillery force ${ }^{11}$.

Beijing has established "defense" or "strategic" dialogues with twenty-six nations and regional organizations since 2005. These include Australia, Brazil, Egypt, the EU, France, Germany, Israel, Jordan, the African Union, Mexico, Nigeria, Peru, Portugal, Russia, South Africa, Syria, Turkey, the United Kingdom, the United States, the United Arab Emirates, and Venezuela ${ }^{12}$. Such agreements vary widely in content and strategic impact. For instance, that with Russia does impart serious nation-to-nation strategic implications; that with say, Portugal, does not.

A list of "The PLA's Top 10 Partners, 2003-2018," in terms of military exercises, "senior level visits," and personnel exchanges is also indicative of the PLA's role in foreign relations. The list includes Russia, the United States, Australia, and New Zealand; the others are Pakistan, Thailand, Singapore, Vietnam, India, and Indonesia ${ }^{13}$.

China thus makes full use of the cultural, diplomatic, economic and military instruments of statecraft when dealing with other nations. In keeping with this paper's focus, Beijing's efforts with the Western world will now be examined.

\section{Europe}

Several European nations were among the imperialists that attacked Chinese sovereignty in the nineteenth and twentieth centuries, contributing to the "century of humiliation," a factor that still affects Beijing's attitude toward relations with Great Britain, France, and others. That history remains an element in Beijing's attitude toward European nations concerned, but its economic relations with the region are extensive and increasing. Tourist and student flows are significant, as are other cultural influences.

The European nations did not all join the United States in its efforts to contain and isolate the PRC from 1949 to 1971 . However, it was only in 1984 that

trade was formalized in the Trade and Cooperation Agreement between China and

11 U.S.-China Economic and Security Review Commission, “2019 Annual Report Section 2: China's Military Reorganization and Modernization: Implications for the United States," (Washington, D.C., 2020), 215, at:

https://www.uscc.gov/sites/default/files/2019-09/Chapter\%202\%20Section\%202-\%20China's\%20 Military\%20Reorganization\%20and\%20Modernization,\%20Implications\%20for\%20the\%20United\%20 States 0.pdf

12 See Appendix B.

13 SAUNDERS, Philip. “China's Global Military-Security Interactions,” in Shambaugh, 202. 
the European Economic Community (EEC), which remains in effect. Military relations also benefited China, as the PLA took advantage of arms sales from European nations, particularly France and Germany ${ }^{14}$.

China deals not just with individual European nations, but also, and perhaps more meaningfully, with the European Union (EU). Britain's recent exit from the EU will no doubt affect Chinese priorities and policies toward Europe, but it is too soon to say to what degree. What is certain is the EU's increasing wariness about China's economic policies and their effects on European well-being, political as well a economic.

China's relations with the EU may have reached a turning point in 2016, when Europeans began at least verbally to speak to an overexpansion of Chinese interests in Europe. Defensive trade measures and a decision against granting "market economy status" to China have substantiated those concerns ${ }^{15}$. This step was perhaps predictable, given the periodic failure of the EU-China High-Level Economic and Trade Dialogue to meet annually, as designed, as well as by failure to agree on the modalities for financing public projects. Despite these concerns, Europe still welcomes Chinese investment which remains prominent, particularly in high technology sectors.

The emergence of a significant PLA role in some of China's investment, including in some cases, outright purchase, of high technology companies has caused further misgivings on Europe's part, but have not significantly constrained continued increases in Chinese economic and political influence in Europe. The negotiations between China and the EU have typified Beijing's strategy of "push-and-shove," meaning no compromise, but only momentary pauses at the negotiating table. Or to paraphrase a senior US diplomat: "the real negotiating begins after the agreement is signed"16.

China also employs the military instrument of statecraft in its dealings with European nations. This has occurred bilaterally during long cruises by ships of China's People's Liberation Army Navy (PLAN), often following their deployment to counterpiracy operations in the Gulf of Aden. PLAN task groups have visited ports throughout the Mediterranean, Black, North Atlantic, North, and Baltic Seas. They have exercised with several of those regions' navies, although on a limited basis; limited, that is, both in frequency and the simplicity of the operations conducted.

14 See "Summary of Treaty," EUROPA Database, at:

http://ec.europa.eu/world/agreements/prepareCreateTreatiesWorkspace/treatiesGeneralData. do?step=0\&redirect=true\&treatyld=341. I toured a PLAN frigate in 1996 and was surprised to fine German-provided Sieman main propulsion diesel engines and a French-supplied helicopter onboard.

15 ELLIOTT, Larry. "European Parliament Gives China a Black Eye Over Trade Status," The Guardian (12 may 2016), at:

https://www.theguardian.com/business/2016/may/12/european-parliament-denies-china-equaltrading-rights

16 See Francois Godement, "China's Relations with Europe," in Shambaugh, 256-260 for a comprehensive look at this relationship; Deb Weidenhamer, "The Contract Is Signed. And Now the Negotiating Begins," New York Times (28 january 2014), at: https://boss.blogs.nytimes.com/2014/01/28/the-contract-issigned-and-now-the-negotiation-begins/ 
Other Chinese military services also have exercised with European partners ${ }^{17}$. The PLA's modernization and reorganization process that began in 2013 headlines a very strong effort to increase the lethality and flexibility of the PLA. The PLA's stated missions include safeguarding "the security of China's overseas interests" and "to participate in regional and international security cooperation and maintain regional and world peace" 18 .

Hence, China uses the PLA as a diplomatic, as well as a military, instrument of statecraft. Its "defense" or "strategic" dialogues with Europe include the EU, France, Germany, Portugal, and the United Kingdom.

A list of "The PLA's Top 10 Partners, 2003-2018," in terms of exercises, "senior level visits," and personnel exchanges does not include the EU or European nations, but they do occur. Furthermore, Europe ranks second on a list of the nubler of senior level military visits, 2003-2018 ${ }^{19}$.

China's relations with Europe during the past forty years have developed a pattern typical of its relations with other nations in general; this is a "carrot and stick" approach. When an economic partner takes a political step of which Beijing disapproves, it applies economic penalties to the nation it blames. The Chinese reaction to perceived slights often seems exaggerated, overly-sensitive, and indicative more of a weak, insecure nation, than one ranking second in the world in economic and political power. Examples include the above-noted examples of the imposition of economic penalties against, Japan, Norway, and the Philippines at various times.

Thus, the Chinese strategic view of Europe is opportunistic, regarding the region as rich in economic benefits. Significant political and military advantages are also perceived, as in benefits gained from the extensive Chinese investment in European seaports and infrastructure projects. Beijing no doubt also sees its strong economic relations with Europe as leverage in its global struggle with the United States ${ }^{20}$.

17 "Chinese, EU Naval Escort Forces Conduct Interactions," China Military Online (9 december 2015); Zoe Stanley Lockerman, "A First: China, EU Launch New Combined Naval Exercise," The Diplomat (18 October 2018), at: https://thediplomat.com/2018/10/a-first-china-eu-launch-new-combined-militaryexercise/; Ryan Pickrell, "Chinese military deploys armored vehicles to Europe for the first time as Chinese medics train in Germany," Military Times (10 july 2019), at: https://www.militarytimes.com/ news/your-army/2019/07/10/chinese-military-deploys-armored-vehicles-to-europe-for-the-first-timeas-chinese-medics-train-in-germany/. Also see the general discussion in "Report to Congress on Chinese Naval Modernization," summarizing the Congressional Research Service Report RL33153 (Washington, D.C.: 23 december 2019), at: https://news.usni.org/2019/12/23/report-to-congress-on-chinese-navalmodernization

18 Defense White Paper, PRC State Council (Beijing: may 2015), at: http://english.www.gov.cn/archive/white paper/2015/05/27/content 281475115610833.htm

19 SAUNDERS, Philip. “China's Global Military-Security Interactions,” in Shambaugh, 202.

20 KAKISSIS, Joanna. "Chinese Firms Now Hold Stakes in Over a Dozen European Ports," NPR (9 october 2018), at: https://www.npr.org/2018/10/09/642587456/chinese-firms-now-hold-stakes-in-over-adozen-european-ports 


\section{United States}

The United States is China's number one international concern. Its view of the United States is complex, with both strongly negative and positive elements. On the negative side is the firmly and widely held view among China's government officials, both civilian and military, as well as its ruling elites, that the United States is determined to contain their country, to prevent it from regaining its historic global prominence, thus threatening the U.S.'s global hegemony. The degree to which these mixed feelings about the United States exist among the Chinese population at large is difficult to measure, but does exist.

U.S. containment in this view has comprehensive goals, including military, economic, political, and social elements. This view also includes U.S., and by extension Western and Japanese, refusal to allow China, with the world's second largest economy and military, from changing the post-World War II international economic, trading, and multilateral political system designed, implemented, and dominated by the United States.

It is neither justified nor sustainable in Beijing's eyes for it to be so artificially constrained in its attempts to modernize and improve the great Chinese nation to the position of global prominence it held for so many years prior to its nineteenth century diminution and eventual collapse, particularly since those catastrophic events were the direct result, in Chinese eyes, of Western and Japanese aggression.

On the economic front, while China's enormous progress since the late 1970s has been due primarily to the efforts of the Chinese people, their efforts were helped immeasurably by the U.S. government-administrations of both political parties-opening the American market to Chinese companies and supporting Chinese membership in the World Trade Organization (WTO) and other international organizations. Washington laid a particularly difficult road for Beijing to travel to join the WTO. Accession finally occurred in 2001; as Beijing has become an active, major member of the organization, its trade profile has improved dramatically.

Perhaps the most basic problem with China's economic and military developments during the last four decades is Washington's view that those developments directly threaten the "international order" fostered and supported by the United States and its allies, post-World War II. This view, at its most extreme, continues to gain currency in the United States - that every Chinese advance is a threat.

Militarily, the United States correctly determined that its Cold War contest with the Soviet Union and international communism would be greatly enhanced by allying with Beijing against Moscow. This policy was seized upon by China following the 1969 conflict with the Soviet Union and harsh relations that lasted until the early 1990s, following the end of the Cold War. Their post-1972 relationship benefitted both China and the United States, but unfortunately has been lost to history as today's "nationalists" in both countries blame the other for various economic, political, and military ills.

The "trade war" launched by President Donald J. Trump in 2018 has contributed to a slowdown of China's economy, but has also substantially hurt sectors of the U.S. economy, 
particularly the agricultural. China's President Xi Jinping may have underestimated the deleterious effects of the trade war's tariffs imposed by Trump, but the latter mysteriously and erroneously keeps insisting that the tariffs equate to money paid by China to the United States.

A "phase one" agreement reached between the two nations in February 2020 may alleviate some of the mutually negative effects of this trade dispute, but they persist, both against the global economy, as well as against the two protagonists ${ }^{21}$. Particularly troubling are calls by U.S. officials for "decoupling" the two economies, a near-impossible goal that would severely constrain both nations' economies and increase uncertainty among global markets ${ }^{22}$.

The U.S. view of China has responded to Beijing's dissatisfaction with equal negative emphasis. The Secretary of Defense, for example, recently described China as

"...the Department's highest priority, as its government continues to use-- and misuse--its diplomatic, economic, and military strength to try to reshape the world in its favor, often at the expense of U.S. interests. The Chinese Communist Party (CCP) continues to invest heavily in the modernization and expansion of its military in areas such as space, cyber, electronic warfare, undersea warfare, fighter aircraft, bombers, longrange missiles, and other anti-access / area denial (A2/AD) capabilities. China's goals are clearly stated: by 2035 , the CCP's leaders seek to complete its military modernization, and, by 2049 , become a preeminent global military power. What is most troubling is that China is pursuing these objectives by any means necessary, including forced technology transfer, intellectual property theft, cyber espionage, and commercial acquisitions. Once Beijing obtains and develops these technologies, it leverages them to intimidate or coerce smaller states, while simultaneously narrowing the United States' competitive advantage" 23 .

China's strategic picture of the United States is complex, containing apparent contradictions, with both strong negative but also significant positive views. For example, the United States is trying to contain China by imposing tariffs and WTO regulations as part of its trade war, designed to limit Chinese economic growth; but the United States provides a vital, major trade and financial partner for China. A second example is Beijing's view of continued U.S. defense treaties in Asia and freedom of navigation operations as impinging

21 The Economist is probably the most useful source of objective analyses of the trade war. Also see, "A Quick Guide to the US-China Trade War," BBC (16 january 2020), at: https://www.bbc.com/news/ business-45899310; “US-China Trade War," South China Morning Post (12 march 2020), at: https://www. scmp.com/topics/us-china-trade-war

22 BROADMAN, Harry G. Forced US-China Decoupling Poses Large Threats," Forbes (30 september 2019), at: $\quad$ https://www.forbes.com/sites/harrybroadman/2019/09/30/forced-u-s-china-decoupling-poseslarge-threats/\#53c4aed1598e

23 Secretary of Defense Mark T. Esper, "Department of Defense Posture Statement to the U.S. Senate Armed Services Committee, 4 march 2020, at: https://www.armed-services.senate.gov/imo/media/doc/ Esper 03-04-20.pdf 
on China's sovereignty; but the U.S. military presence serves a stabilizing influence re the Korean peninsula and historic Japanese aggression ${ }^{24}$.

Sino-American relations are increasingly tenuous regarding economic, military, political, and even cultural relations, as 2020 disputes regarding the COVID-19 Virus evidence.

\section{Latin America}

Latin America, defined here to include South and Central America, Mexico, and the Caribbean nations, covers more than 12 percent of the globe. Its geography, demographics, economies, governance systems, and foreign priorities cover an amazing variety of topography, political systems, and ethnicity. Its natural resources are legion, and have long provided the dominant interest to other nations seeking interest and investment in Latin America. China has followed this precedent, with its primary interests economic, focusing on Venezuela's oil, Brazil's soybeans, and other commodities. The region also offers Brazil's state-of-the-art aircraft manufacturing industry, deep-sea oil drilling technology, and other pockets of advanced technology.

Latin America receives more than 10 percent of China's foreign investment ${ }^{25}$. That is not an insignificant amount, but fails to match the expectations raised during Chinese President Hu Jintao's highly publicized, two-week tour of the region in 2004, when he visited Argentina, Brazil, Chile, and Cuba following attendance at the Valparaiso meeting of the Asia Pacific Economic Cooperation forum (APEC), which included estimates of $\$ 100$ billion in Chinese investment in the region ${ }^{26}$. The newsworthiness of Hu's visit was heightened by U.S. President George W. Bush's very brief attendance at the APEC meeting, and no follow-on visits in the region. This contrast resulted in reviews positive for $\mathrm{Hu}$ and negative for Bush.

China's efforts to improve relations with Latin America gained impetus following institution of Deng Xiaoping's economic modernization programs. Many of the region's nations shifted their diplomatic recognition from Taibei to Beijing between 1970 and1984. One of Deng's efforts that applied directly to the region was improving "south-south cooperation" to improve China's political and economic relations with developing countries, with a goal of increasing access to raw materials and international position.

The increase in China's relations with Latin American countries continued to expand and improve during the 1990s; indeed, by the end of that decade, Latin America had become a prime target for Chinese political and economic partnership ${ }^{27}$. This trend has

24 My conversations with senior Chinese military officers and academics at various times, 1994-2017.

25 NAUGHTON, Barry. "China's Global Economic Interactions," in Shambaugh, Figure 6.5, 131, gives this figure for just "South America".

26 A summary of articles and interviews from China's Ministry of Foeign Affairs concerning Hu's visits to Latin America is at: https://www.fmprc.gov.cn/mfa eng/topics 665678/huvisit 665888/

27 JENKINS, Rhys. "Latin America and China: A New Dependency?", Third World Quarterly 33, 7 (2012), 1137-1158, at: 
topped out, however, with 2019 one of the lowest on record for Chinese "state-to-state" financing, with approximately $\$ 1.1$ billion loaned from Chinese banks to in Latin American governments and state-owned enterprises. Notable loans were made to Argentina, the Dominican Republic, Suriname, and Trinidad and Tobago ${ }^{28}$.

Free Trade Agreements were signed with Peru and Costa Rica in 2009 and 2010, respectively; Beijing has announced "strategic partnerships" with Argentina, Brazil, Chile, Mexico, Peru, and Venezuela.

China published a "Policy Paper on Latin America and the Caribbean" in $2016^{29}$. This expressed Beijing's economic, political, social, and military goals for the region, thoroughly blanketed in a mantra of "partnership," "cooperation," and "win-win." A threatening thread throughout the white paper was implied rather than stated outright. This conditioned regional nations' good relations with China on not recognizing or conducting extensive relations with Taiwan; not supporting Tibetan interests, including particularly recognizing the Dali Lama; not expressing criticism of Beijing's actions against its Muslim citizens, especially those in Xinjiang, or otherwise criticizing China.

The 2016 Policy Paper is a landmark publication, expressing policies both clear and potentially beneficial both to China and the targeted countries. Hence, its four parts will be discussed in some detail. Part I is a brief blandishment aimed at Latin America and the Caribbean.

Part II cites important precedents for improved Sino-Latin American relations. The first is the 2008 Chinese government's paper advocating a "comprehensive and cooperative partnership" with the region. The second followed a 2014 meeting between Chinese and Latin American leaders in Brasilia. The conference's concluding statement included a "comprehensive and cooperative partnership of equality, mutual benefit and common development." It was followed by the "Forum of China and the Community of Latin America and Caribbean States (China-CELAC Forum)," established as a platform for future cooperative efforts.

Part III of China's Latin America Policy Paper, "Bringing the Comprehensive and Cooperative Partnership to New Heights" is a variation on the Five Principles of Peaceful Coexistence, offering five goals:

(1) sincerity and mutual trust in the political field, (2) win-win cooperation on the economic front, (3) mutual learning in culture,

https://www.tandfonline.com/doi/abs/10.1080/01436597.2012.691834

28 MYERS, Margaret and GALLAGHER, Kevin. "Scaling Back: Chinese Development Finance in LAC, 2019," The Dialogue (18 march 2020), at:

https://www.thedialogue.org/analysis/scaling-back-chinese-development-finance-in-lac-2019/

29 "Full Text of China's Policy Paper on Latin America and the Caribbean," State Council of the PRC (Beijing: 24 november 2016), available at:

http://english.www.gov.cn/archive/white paper/2016/11/24/content 281475499069158.htm The following discussion draws heavily on this Policy Paper. 
close coordination in international affairs, and mutual reinforcement between

China and the region as a whole, and between China and the individual nations of the region.

Another significant diplomatic step was Beijing's 2015-2019 “China-Latin American and Caribbean Countries Cooperation Plan," focused on trade and investment. It emphasized financial cooperation to help identify "energy and resources, infrastructure construction, agriculture manufacturing scientific and technological innovation and information technology" as priorities for "jointly building logistics, electricity and information" in the region, while "expanding the three financing channels of funds, credit loans and insurance." The China-CELAC forum is supposed to support these objectives.

Part IV addressed the means for furthering these objectives, namely

(1) High-Level Exchanges,

(2) Exchanges of Experience on Governance,

(3) Inter-governmental Dialogue and Consultation Mechanisms,

(4) Exchanges Between Legislatures,

(5) Exchanges Between Political Parties, and

(6) Local Exchanges.

The Cooperation Plan's particulars for the "Economic Field" are unexceptionable: trade, economic and technical assistance, cooperation for industrial investment and capacity, financial programs, energy and resources production, infrastructure development, manufacturing, agriculture, space, maritime affairs, customs and quality inspection, trade and investment promotion institutions and business associations of the two sides, as well as scientific and technological innovation.

These objectives are further defined to include "Social Aspects," such as social governance and development; environmental protection, climate change and disaster reduction; poverty reduction; and health cooperation. The White Paper then addresses the "Cultural and People-to-People Fields," specifically:

cultural and sports exchanges and cooperation, education and human resources training, press-publication-radio-film-television exchanges and cooperation, tourism cooperation, exchanges between think tanks, academic institutions, and non-governmental organizations, and consular cooperation.

Next, proposed "International Collaboration" addresses "international political affairs, global economic governance, implementation of a 2030 agenda for sustainable development, response to climate change, and cyber security."

Finally, "Peace, Security and Judicial Affairs" would include cooperation in military exchanges, judicial and police affairs, all addressed through "collective cooperation" and "Trilateral cooperation". 
In short, China's 2016 White Paper on Latin America and the Caribbean is a long list of platitudes and well-sounding programs, all dependent on Beijing's approval, based in turn on what the former Foreign Minister Yang Jiechi described as China's priority as a "large country," opposed to to the "small countries" of Latin America and the Caribbean.

China's Cooperation Plan certainly aims to maximize its own benefits, but still offers opportunities to Latin American nations tired of the U.S.'s historically inconsistent and often domineering policies and attitude toward the region. It is worth noting that Brazil is China's most prolific trade partner in Latin America. This is due chiefly to Beijing's need to purchase the soybeans that are abundantly grown in Brazil, a factor exacerbated by the U.S.-initiated trade war with China.

A prominent Chinese-Latin American economic relationship is embodied in "One Belt, One Road" now called the "Belt and Road initiative" (OBOR or the BRI) announced by President Xi Jinping in 2013 and extended to Latin America at the 2018 China-CELAC ministerial forum. Nineteen regional countries have since joined the program ${ }^{30}$. These are Antigua \& Barbuda, Barbados, Bolivia, Chile, Cuba, Dominica, the Dominican Republic, El Salvador, Grenada, Guyana, Jamaica, Panama, Paraguay, Trinidad and Tobago, Uruguay and Venezuela. Argentina, Brazil, Colombia, and Mexico appear to view the BRI favorably, but have yet to sign on with Beijing ${ }^{31}$.

The benefits to members are promising, but yet fully to be realized. BRI is not a multilateral organization, but a series of bilateral agreements between China and the correspondent countries. These agreements depend in large part on Chinese financing, usually by the China Development Band (CDB) and Export-Import Bank (Eximbank), focusing on building infrastructure improvements in the recipient countries.

Another important Chinese program aiming at international trade and financing is the Asia Infrastructure Investment Bank (AIIB), organized in 2014. AlIB is advertised as "a multilateral bank," but it is Chinese in origin, original funding (30 percent), voting rights (26 percent), location (Beijng), and leadership (Jin Liqun). Neither Japan nor the United States are AIIB members, a decision that seems to have accrued no benefit to either. One hundred nations have joined the AIIB as of April 2019, including many Western but few Latin American nations, just Brazil, Guinea, Hungary, Uruguay, and Venezuela. Bolivia has been trying to join, but has missed required deadlines, apparently because of bureaucratic turmoil ${ }^{32}$.

30 See Andrew Chatzky and James MacBride, "China's Massive Belt and Road Inititative" (New York: Council on Foreign Relations, 28 january 2020), at: https://www.cfr.org/backgrounder/chinas-massive-belt-androad-initiative. Also, Margaret Myers, "Remarks at Inter-American Dialogue and Universidad del Pacífico Conference on the BRI," Lima, Peru (2 march 2020), at: https://www.thedialogue.org/events/the-briand-latin-america-prospects-and-implications/

31 ZHANG, Pepe. "Belt and Road in Latin America: A Regional Game," The Atlantic Council (8 october 2019), at: $\quad$ https://www.atlanticcouncil.org/in-depth-research-reports/issue-brief/belt-and-road-in-latinamerica-a-regional-game-changer/.

32 MENDEZ, Alvaro and TURZI, Mariano. The Political Economy of China-Latin American Relations: The AllB Membership, (Cham, Switzerland: Palgrave Macmillan, 2020), 99, at: https://books.google.com/ books?id=TzzYDWAAQBAJ\&pg=PA95\&lpg=PA95\&dq=venezuela+in+the+aiib\&source=bl\&ots=hjZURmPzyW\&sig=ACfU3U3rdIIWlwZF478nTqGf57ngfzKG9Q\&hl=en\&sa=X\&ved=2ahUKEwiQu7eSxrDoAhXLhHIE- 
Membership now accounts for "78 percent of the world's population and 63 percent of global GDP"33.

This may be viewed as a competitor to the Western-organized World Bank and other regional banks, such as the Development Bank of Latin America (CAF) and the Inter-American Development Bank (IDB). In fact, there are more than enough global development project requirements globally to require the assistance of all such existing banks. In any event, as of october 2019 Beijing announced some impressive figures, that "136 countries and 30 international organizations have signed194 Belt and Road cooperation documents with the Chinese side." This was supplemented by a December speech by Foreign Minister Wang Yi that in 2019, "China has signed documents on Belt and Road cooperation with 16 countries and international organizations, bringing the total number of such cooperation documents to $199^{\prime \prime} 34$.

Xi has continued a program of summit meetings with Latin American leaders and in 2015, Chinese Prime Minister Le Keqiang agreed with his Brazilian and Peruvian counterparts to study the feasibility of constructing a railroad from the Atlantic to Pacific coasts, called the "Twin-Ocean Rail," a project initially proposed by Xi in 2013. No progress appears to have been made on this project, other than a planning office established in China in $2018^{35}$.

China has conducted an extensive effort to acknowledge the importance of Latin American regional organizations. It is an observer to the Organization of American States (OAS) and has "ties" with the Group of Rio, the Andean Community, and the Caribbean Community (Caricom). China has made particular efforts to establish closer relations with the members of Mercosur, the important Latin American regional Customs Union that includes Argentina, Brazil, Paraguay, and Uruguay. Mercosur is the world's fourth largest trading bloc smaller only than the European Union, the North American Free Trade Association, and the Association of Southeast Asian Nations. Bolivia, Chile, Ecuador, Guyana, Peru, and Suriname are Mercosur Associate Members; Mexico and New Zealand hold observer status, while Venezuela's membership has been suspended since 2016. Mercosur also has a customs agreement with South Africa, which joins China and Brazil in the BRICS Association, composed of Brazil, Russia, India, China, and South Africa ${ }^{36}$.

HYG0B58Q6AEwEnoECAoQAQ\#v=onepage\&q=venezuela\%20in\%20the\%20aiib\&f=false.

33 "AIIB Reaches 100-Member Milestone," AIIB (13 june 2019), at: https://www.aiib.org/en/news-events/ news/2019/20190713 001.html.

34 The first figures were in Yang Han, "ASEAN Sees Key Role for BRI Projects," China Daily (21 october 2019), at:

https://www.chinadaily.com.cn/a/201910/21/WS5dad0fe2a310cf3e3557198f.html Wang Yi's speech, "Braving Waves and Sailing Forward with Resolve (13 december 2019), was quoted in https://www.fmprc.gov.cn/mfa eng/wjb 663304/wjbz 663308/2461 663310/t1724306.shtml.

35 "Sino-Latin American Joint Laboratory of Rail Transit Unveiled," State Laboratory of Traction Power, Southwest Jiaotong University (30 may 2018), at: http://tpl.swjtu.edu.cn/shownews-27291.html. Even more ambitious (bizarre?) was Li's proposal for a "Two Ocean Tunnel," extending from the Buenos Aires area to Chile's coast, near Valparaiso.

36 See "Linking Belt and Road With Mercosur," OBOR News (21 november 2019), at: https://obor.news/ linking-belt-road-with-mercosur/? cf chl jschl tk $=9418 \mathrm{cb} 21 \mathrm{~b} 43 \mathrm{~b} 2 \mathrm{~b} 29 \mathrm{cc} 44 \mathrm{ccba397c7ae7cb}$ 9a0def-1583873160-0-AU5mgehOevvPmiZrmp5D7z8TpnyV2YVErBXFNa4cgzN1RuIP0ARE3ozFVvd 
Beijing includes the military as well as the economic instrument of statecraft in its relations with Latin America. The PLAN hospital ship, Daishan (Peace Ark) has visited Cuba, Jamaica Trinidad and Tobago, Costa Rica, and Venezuela ${ }^{37}$.

A Chinese navy task group of two warships and a supply ship also visited Cuba, in 2015 , then proceeding to Acapulco, Mexico en route home ${ }^{38}$. More significant than a few ship visits has been the number of Latin American military students attending courses in China as well as the numerous exchanges and visits by Chinese and regional officials, both military and civilian. That said, the number of Latin American students attending U.S. military educational and training institutions dwarfs those going to China. Limited arms sales have flowed from China to Bolivia and a few other regional nations, while significant military technology deals are in place between Beijing and Brasilia and Beijing and Buenos Aires $^{39}$. Again these exchanges and arms sales remain dwarfed by similar agreements and relationships between Latin America and the United States and Europe.

China has focused attempts to increase military cooperation on Bolivia and Venezuela, although efforts have also been made with Argentina, Brazil, and Peru. Despite its continuing attempts to increase its economic, military, and political relations with Latin America, China's relatively cautious approach to the region is influenced by concerns about intruding into what historically has been a U.S. "back yard."

That U.S. policies and relations with the region historically have been marked by many false starts and unfulfilled promises has not terminally affected the strong historic, economic, political, and military linkages between Washington and its southern neighbors. Hence, It was only after Xi Jinping took office that Beijing began more directly to increase its stake and expand its presence in Latin America. Xi's formal visit to the region in 2013 gave rise to his call for creating a "China-Latin America community of common destiny," which with the above-noted CELAC indicates a Chinese desire to create an economic and political "sphere of influence" in the region ${ }^{40}$. Beijing was and is concerned about gar-

H90aS4-OYyBKCXz9xCFxT4eCdfeZO2DS5DMrSqSjlqOUspL eznc9PbLw7RnDaJ8X JgwZwlqt hogu06uvlYP56gfSH6yN0 358alKiadZbS3WSXP3bki69ULsawuKKiz4ufsZ671-GWvF64r4jNqJvT1La oZrOg AzJgF4neDhgdKIIzJNRrqLbkFxVocucjyhIThUTgKQc1SL3U75ZsU2Yve7NLz6JLhZ4CJODRkDobaQTNMJXtGtJU6NaPPvEHew. BRICS is described at Christina Majaski, "Brazil, Russia, India, China," Investopedia (updated 27 January 2020), at: https://www.investopedia.com/terms/b/bric.asp

37 FRANKS, Jeff. "Chinese Navy Hospital Ship Visits Cuba and Caribbean," Reuters (21 october 2011), at: https://www.reuters.com/article/idINIndia-60058520111021; “China Navy Ship Visits Venezuela for the First Time as Maduro Cozies up to Beijing," Reuters (23 september 2018), at: https://www.businessinsider. com/r-china-navy-ship-makes-maiden-visit-to-venezuela-after-maduro-visit-2018-9

38 "Chinese Warships Visit Cuba for Exercises," Havana Times (10 november 2015), at: https://havanatimes. $\mathrm{org} /$ news/chinese-warships-visit-cuba-for-exercises/; "Chinese Naval Warships Wrap Up Visit to Mexico," China Military Online (30 november 2015), at: http://english.chinamil.com.cn/news-channels/ china-military-news/2015-11/30/content 6792960.htm

39 MARCELLA, Gabriel. "China's Military Activity in Latin America," Americas Quarterly (Winter 2012), at: https://www.americasquarterly.org/Marcella.

40 See the discussion in Lei Yu, “China's Strategic partnership With Latin America: A Fulcrum in China's Rise," International Affairs, 91, 5 (Oxford, UK, The Royal Institute Of International Affairs, 2015), 10471068, at:

https://onlinelibrary.wiley.com/doi/abs/10.1111/1468-2346.12397. 
nering Latin American support in international fora, especially the UN.

China's economic relationship with Latin America is significant but should not be exaggerated. Its trade with the region has indeed grown, from US\$15 billion in 2001 to US\$260 billion in 2014, an impressive 30 percent growth rate per annum ${ }^{41}$. Chinese loans to Latin American countries is shown in Appendix B.

While China in 2018 became South America's most important export market, it remained second to the United States for all of Latin America. The region's trade balance with China improved in 2018; Chinese direct investment in the region fell in all categories; and Chinese lending continues to be concentrated on a few borrowing countries, overwhelmingly - two/thirds to Venezuela, with Bolivia, Ecuador, and Argentina other significant recipients. At least seven Latin American countries have joined the AllB ${ }^{42}$.

China's political relationships with Latin American nations include the role played by Taiwan, the self-styled Republic of China (ROC). During the past three years, those regional nations recognizing the ROC instead of the PRC declined by three, as the Dominican Republic, El Salvador, and Panama shifted diplomatic recognition from Taibei to Beijing. Belize, Guatemala, Haiti, Honduras, Nicaragua, Paraguay, Saint Kitts and Nevis, Saint Lucia, and Saint Vincent and the Grenadines are the only Latin American states that still recognize the ROC.

Beijing's drive to have nations shift diplomatic recognition to the PRC is driven primarily by national pride and strategic objectives. Motivation of the Latin American nations who recently have made that shift likely is driven primarily by economic reasons, signing up to the BRI, in particular. Former president of Panama Juan Carlos Varela stated in 2019 that the BRI is "all about connectivity and Panama is one of the most connected countries in the region." Panama was the first Latin American nation to sign up to the BRI and was followed by the Dominican Republic and El Salvador. A total of nineteen Latin American nations had signed bilateral BRI agreements with China by mid- $2019^{43}$.

China's strategic approach to Latin America has been and continues to be cautious and methodical. Diplomacy leads Beijing's policies, with economic relationships forming the basis and the structure of China's relations with the region. The PLA has been used sparingly, with an emphasis on establishing personal relationships, with minimal arms sales and unit exchanges. Beijing's large investments in a questionable partner has so far been restricted to Venezuela. Its focus on the "ABC" countries is more traditional and understandable.

41 Ibid. 1049.

42 RAY, Rebecca and WANG, Kehan, "China-Latin America Economic Bulletin, 2019 Edition," Boston University Global Development Policy Center, 2020, at: www.bu.edu/gdp is an excellent source. Also see n. 25, above.

43 "Weighing the Effects of Taiwan-China Competition in Latin America and the Caribbean," The Dialogue (29 july 2019), at: https://www.thedialogue.org/analysis/weighing-the-effects-of-taiwan-china-competitionin-latin-america-and-the-caribbean/ 


\section{Conclusion}

This brief discussion has noted several remarkable periods in the history of the PRC during its seventy-one years of its existence. The relative isolation of its first three decades ended with Deng Xiaoping's firm grasp of power in the late 1970s. He initiated a period during which China rejoined the modern world, including its dominating, Western-originated economic and multilateral organizations.

The nation's remarkable economic progress was felt most significantly at home, but also launched China onto the path it has now followed to become the world's first or second richest nation ${ }^{44}$. It had also, by the time of Deng's death in 1997, began the military modernization that has led to the emergence of the PLA as the second most powerful military in the world and, more significantly, the most powerful in East Asia by almost any standard.

China has achieved a relatively balanced economic relationship with the international community. Its three double-digit-percentage trading partners, as of 2010, were the EU,16.1 percent; the United States, 13 percent; and Japan, 10 percent. Other Asian nations (ASEAN, Hong Kong, South Korea, Taiwan, India, and Australia) totaled 34.6 percent, while China's most significant Latin American trading partner, Brazil, ranked at 2.1 percent. The remaining Latin American nations were part of the "Others, 24.3 percent" of China's international trade ${ }^{45}$.

Deng's revolutionary rule was followed by a period of relative entrenchment, but still remarkable economic and military growth under the leadership of Jiang Zemin and $\mathrm{Hu}$ Jintao. While neither of these leaders has gained the renown of either Deng or Xi, they offered a consistent leadership following Deng's revolutionary changes to China's character and methods of governance. In fact, it was Jiang and Hu who at the turn of the century fostered the "going out" strategy, a national policy designed to take advantage of China's already large foreign reserves to obtain the natural resources necessary to support the nation's continued economic expansion and modernization ${ }^{46}$.

The "fifth generation" leadership of Xi Jinping has both built upon and expanded China's global strength in economic, military, diplomatic, and political strength. At the June 2018 Foreign Work Affairs Conference, Xi emphasized the importance of working with "developing states," focusing on Africa, the Middle East, and Latin America. He particularly noted the importance of Argentina, Brazil, and Mexico as on a par with "traditional major powers" ${ }^{47}$.

44 Economically, China ranks number two, behind the United States measured in per capita gross domestic product (GDP), but number one if measured in the more ephemeral Purchasing Power Parity (PPP).

$45 \mathrm{Yu}, 1062$.

46 WANG, Hongying. “A Deeper Look at China's 'Going Out’ Policy,” ClGI (8 march 2016), at: https://www. cigionline.org/publications/deeper-look-chinas-going-out-policy; Paul Nash, “China's 'Going Out' Strategy," Diplomatic Courier 10 may 2012), at: https://www.cigionline.org/publications/deeper-look-chinas-going-out-policy 
China's political, military, and economic strategic goals are coherent and their progress relatively closely coordinated. Hence, Beijing is willing to accept significant economic losses, if it serves its strategic interests. In Venezuela, for instance, China is estimated to have "lost billions of dollars in contracts and capital, but perseveres in maintaining close relations with that failing state" 48 . Overall, according to one source, China's foreign investments were down 41 percent in 2019. This downturn is almost certainly being increased by the corona virus pandemic, particularly for the flagship BRI program. No matter the actual origin of this virus, it first emerged as a problem in China; it currently has caused many problems in the development and administration of BRI projects ${ }^{49}$.

China in 2020 has never presented a stronger global presence in its thousands of years of history. However, as is the case with all aspects of Chinese governance, including domestic policies and international relations, the number one priority is to support the rule of the CCP. No domestic or foreign policy or program that does not fulfill that role will not be implemented or, if perceived to have failed, will be discarded.

$\begin{array}{ll}\text { APPENDIX A: COUNTRY AND LOANS AMOUNT (U.S. \$) } \\ \text { Venezuela } & \$ 62.2 \text { Billion (B) } \\ \text { Brazil } & \$ 28.9 \mathrm{~B} \\ \text { Ecuador } & \$ 18.4 \mathrm{~B} \\ \text { Argentina } & \$ 17.1 \mathrm{~B} \\ \text { Trinidad \& Tobago } & \$ 2.7 \mathrm{~B} \\ \text { Bolivia } & \$ 2.4 \mathrm{~B} \\ \text { Jamaica } & \$ 2.1 \mathrm{~B} \\ \text { Mexico } & \$ 1.0 \mathrm{~B} \\ \text { Dominican Rep. } & \$ 600 \mathrm{Million}(\mathrm{M}) \\ \text { Suriname } & \$ 580 \mathrm{M} \\ \text { Costa Rica } & \$ 395 \mathrm{M} \\ \text { Cuba } & \$ 240 \mathrm{M} \\ \text { Guyana } & \$ 175 \mathrm{M} \\ \text { Barbados } & \$ 170 \mathrm{M} \\ \text { Bahamas } & \$ 99 \mathrm{M} \\ \text { Peru } & \$ 50 \mathrm{M}\end{array}$

APPENDIX B. CHINA'S STRATEGIC PARTNERS ${ }^{50}$

48 Ibíd. 301.

49 RUSSEL, Daniel. "The Coronavirus Will Not be Fatal for China's Belt and Road initiative but it Will Strike a Heavy Blow," South China Morning Post (19 march 2020), at: https://www.scmp.com/comment/opinion/ article/3075624/coronavirus-will-not-be-fatal-chinas-belt-and-road-initiative-it. A Russian source, Nezavisimaya Gazeta (19 March 2020), at: http://www.ng.ru/world/2020-03-19/1 7822 china.html (in Russian), opined that "the epidemic that originated in China has weakened tis international influence," with restrictions on Chinese workers "introduced by more than 130 countries".

50 This list of various categories of China's strategic relationships is from Feng Zhongping and Huang Jing, 
REGIONS Americas (8)

\begin{tabular}{|c|c|}
\hline Brazil & 1993 \\
\hline USA & 1997 \\
\hline Venezuela & 2001 \\
\hline Mexico & 2003 \\
\hline Argentina & 2004 \\
\hline Canada & 2005 \\
\hline Peru & 2008 \\
\hline Chile & 2012 \\
\hline Australia & 2013 \\
\hline South Africa & 2004 \\
\hline Nigeria & 2005 \\
\hline Angola & 2010 \\
\hline Algeria & 2014 \\
\hline African Union (AU) & 2006 \\
\hline Russia & 1996 \\
\hline France & 2004 \\
\hline Germany & 2004 \\
\hline Italy & 2004 \\
\hline UK & 2004 \\
\hline Spain & 2005 \\
\hline Portugal & 2005 \\
\hline Greece & 2006 \\
\hline Denmark & 2008 \\
\hline Serbia & 2009 \\
\hline Ukraine & 2011 \\
\hline Poland & 2011 \\
\hline Ireland & 2012 \\
\hline Belarus & 2013 \\
\hline European Union (EU) & 2003 \\
\hline
\end{tabular}

Oceania (1) Africa (5)

“China's Strategic Partnership Diplomacy," ETH Zurich Center for Security Studies (June 2014), at: https://css.ethz.ch/en/services/digital-library/publications/publication.html/181324 


\section{Europe (15)}

China's strategic partnership diplomacy: engaging with a changing world

\begin{tabular}{|c|c|}
\hline Pakistan & 2005 \\
\hline Kazakhstan & 2005 \\
\hline India & 2005 \\
\hline Indonesia & 2005 \\
\hline South Korea & 2008 \\
\hline Vietnam & 2008 \\
\hline Laos & 2009 \\
\hline Cambodia & 2010 \\
\hline Turkey & 2010 \\
\hline Mongolia & 2011 \\
\hline Myanmar & 2011 \\
\hline Thailand & 2012 \\
\hline Uzbekistan & 2012 \\
\hline United Arab Emirates & 2012 \\
\hline Afghanistan & 2012 \\
\hline Tajikistan & 2013 \\
\hline Sri Lanka & 2013 \\
\hline Turkmenistan & 2013 \\
\hline Kyrgyzstan & 2013 \\
\hline Malaysia & 2013 \\
\hline $\begin{array}{l}\text { Association of Southeast } \\
\text { Asian Nations (ASEAN) }\end{array}$ & 2003 \\
\hline
\end{tabular}

Asia (21) 